\title{
Increased Endothelin-1-Mediated Vasoconstrictor Tone in Human Obesity: Effects of Gut Hormones
}

\author{
F. SCHINZARI ${ }^{1}$, M. TESAURO ${ }^{2}$, C. CARDILLO ${ }^{1,3}$ \\ ${ }^{1}$ Policlinico A. Gemelli, Rome, Italy, ${ }^{2}$ Department of Internal Medicine, Università Tor Vergata, \\ Rome, Italy, ${ }^{3}$ Department of Internal Medicine, Università Cattolica del Sacro Cuore, Rome, Italy
}

Received November 29, 2017

Accepted February 2, 2018

\section{Summary}

The heavy impact of obesity on the development and progression of cardiovascular disease has sparked sustained efforts to uncover the mechanisms linking excess adiposity to vascular dysfunction. Impaired vasodilator reactivity has been recognized as an early hemodynamic abnormality in obese patients, but also increased vasoconstrictor tone importantly contributes to their vascular damage. In particular, upregulation of the endothelin (ET)-1 system, consistently reported in these patients, might accelerate atherosclerosis and its complication, given the pro-inflammatory and mitogenic properties of ET-1. In recent years, a number of gut hormones, in addition to their role as modulators of food intake, energy balance, glucose and lipid metabolism, and insulin secretion and action, have demonstrated favorable vascular actions. They increase the bioavailability of vasodilator mediators like nitric oxide, but they have also been shown to inhibit the ET-1 system. These features make gut hormones promising tools for targeting both the metabolic and cardiovascular complications of obesity, a view supported by recent large-scale clinical trials indicating that novel drugs for type 2 diabetes with cardiovascular potential may translate into clinically significant advantages. Therefore, there is real hope that better understanding of the properties of gut-derived substances might provide more effective therapies for the obesity-related cardiometabolic syndrome.

\section{Key words}

Obesity • Vascular dysfunction • Endothelin-1 • Insulin resistance - Gut hormones

\section{Corresponding author}

C. Cardillo, Istituto di Patologia Speciale Medica e Semeiotica
Medica, Università Cattolica del Sacro Cuore, Largo Gemelli 8, 00168 Rome, Italy. Fax: +39 (06) 3015-7232. E-mail: carmine.cardillo@unicatt.it

\section{Introduction}

The incidence of obesity and type 2 diabetes is still increasing worldwide at an alarming rate, in relation predominantly to lack of regular physical activity and consumption of high fat/sugar diets, and carries a heavy burden in terms of morbidity, mortality and health carerelated costs. One direct consequence of obesity is the rising incidence of type 2 diabetes, which occurs when insulin resistance is present and insulin secretion fails to compensate. Another unwanted complication of excess body weight is the development and progression of cardiovascular disease, with multiple, complex mechanisms underlying this relationship. Of note, the rate of obesity-related cardiovascular consequences is higher in those individuals with excessive visceral fat accumulation that predispose them to the metabolic syndrome, an association of hypertension, disglycemia and lipid abnormalities that occurs as a consequence of insulin resistance (Ahima and Lazar 2013). In contrast with this "metabolically unhealthy" phenotype, obese patients with predominant fat storage in the subcutaneous adipose tissue seem to possess a metabolically inert profile, the so called "metabolically healthy obesity". In these individuals, it is likely that subcutaneous adipose tissue acts as a safe depot for potentially toxic lipids produced in excess, thereby leading to improved metabolic and cardiovascular health due to preserved 
insulin sensitivity, absence of diabetes and reduction of other risk factors for cardiovascular disease (Lee et al. 2013, Wildman et al. 2008).

\section{Vascular abnormalities in human obesity}

Over the last couple of decades, a number of studies performed in the human circulation in vivo have defined the main mechanisms underlying obesity-related vascular dysfunction.

\section{Impaired vasodilator responsiveness}

Steinberg et al. (1996) first reported that, compared to lean controls, insulin resistant patients with high body mass index (BMI) or type 2 diabetes have blunted leg blood flow response to graded doses of acetylcholine, which is known to be largely mediated by endothelial release of nitric oxide (NO). These results were later replicated by Van Guilder et al. (2006), who reported impaired endothelium-dependent vasodilation in normotensive and normoglycemic obese adults, and by Weil et al. (2011), who observed that the forearm flow response to acetylcholine is lower in overweight/obese individuals than in lean controls. In a larger investigation performed in our laboratory, we have observed that obese patients have impaired vasodilator response not only to acetylcholine but also to sodium nitroprusside, an endothelium-independent $\mathrm{NO}$ donor, hence suggesting impaired vascular smooth muscle responsiveness to NO in these patients (Schinzari et al. 2015), probably due to defects in the NO/cyclic GMP/protein kinase G pathway and/or to increased oxidative stress (Christou et al. 2012). Of note, among the obese patients included in our study, those with metabolically "unhealthy" obesity, defined as the presence of at least one glucose or lipid abnormality characteristic of the metabolic syndrome, had further impairment in the responsiveness to acetylcholine, but not to sodium nitroprusside, compared to their metabolically healthy counterpart; this observation suggests that coexistence of metabolic changes sums further endothelial impairment to the vascular dysfunction induced by obesity in itself.

\section{Increased endothelin (ET)-1-dependent vasoconstriction}

Another relevant feature of the obesity-related vasculopathy is enhancement of the vasoconstrictor tone, related predominantly to increased activity of the ET-1 system. The first evidence in this regard was reported by Mather et al. (2004), who investigated the interactions between the ET-1 and NO systems in the vasculature of obese or type 2 diabetic individuals. They observed that antagonism of ET-1 by use of BQ-123, a selective blocker of $\mathrm{ET}_{\mathrm{A}}$ receptors, is able to correct the defect in endothelium-dependent vasodilation seen in these patients. In a study performed in our laboratory to investigate whether enhanced ET-1 activity in hypertensive patients is related to increased body mass (Cardillo et al. 2004), we observed that overweight and obese patients had a significant vasodilator response to $\mathrm{ET}_{\mathrm{A}}$ blockade, whereas lean hypertensive participants did not. In contrast, BQ-123 administration did not determine any significant hemodynamic change in normotensive controls, irrespective of their body mass. Of note, a significant association was observed between BQ-123induced vasodilation and BMI in patients with hypertension but not in normotensive controls, thereby indicating a selective enhancement of $\mathrm{ET}_{\mathrm{A}}$-mediated vasoconstriction in the former group. This abnormal $\mathrm{ET}_{\mathrm{A}}$-dependent vascular response in the presence of hypertension and elevated BMI may be secondary to either increased availability of ET- 1 at the $\mathrm{ET}_{\mathrm{A}}$ receptor level or to enhanced vasoconstrictor responsiveness to ET-1. To gain a more precise mechanistic insight, we then assessed the response to exogenous ET-1 in our study groups. As the vasoconstrictor response in the obese normotensive participants did not differ from that observed in the obese hypertensive group, our results indicate that ET-1-mediated vasoconstriction in obesity is independent of blood pressure values and hence suggest that enhanced ET-1 synthesis is the likely mechanism underlying the increased $\mathrm{ET}_{\mathrm{A}}$-dependent tone in obese hypertensive patients. In another investigation, we assessed whether patients with the metabolic syndrome present enhanced vascular ET-1 activity (Tesauro et al. 2009). We observed that $\mathrm{ET}_{\mathrm{A}}$ antagonism with $\mathrm{BQ}-123$ elicits a significantly higher vasodilator response in patients with the metabolic syndrome than in controls, confirming that an enhanced ET-1 vasoconstriction tone is present in these patients. In addition, NO synthase inhibition with L-NMMA during $\mathrm{ET}_{\mathrm{A}}$ receptor blockade was associated with lower vasodilator response in lean patients than in lean controls, consistent with impaired NO bioactivity in the obese vasculature. Given the inhibitory effect of $\mathrm{NO}$ on the endothelial production of ET-1 (Boulanger and Luscher 1990), it is likely that reduced NO availability plays a role in the enhanced ET-1 mediated vasoconstrictor tone in these patients. To further expand the understanding of ET-1 system 
activation in obesity, Weil and colleagues (2011) conducted an investigation to assess if ET-1-mediated vasoconstrictor tone is elevated in overweight and obese adults independent of other cardiovascular risk factors and, if so, to determine whether the enhanced vascular ET-1 activity contributes to the impairment in endothelium-dependent vasodilation in these two populations (Weil et al. 2011). Consistent with the main hypotheses, the overweight and obese participants showed a blunted forearm vasoconstrictor response to acetylcholine compared with those with normal weight; also, selective $\mathrm{ET}_{\mathrm{A}}$ receptor blockade induced a significant forearm vasodilator response in the overweight and obese groups but not in the lean participants; and finally, selective $\mathrm{ET}_{\mathrm{A}}$ receptor blockade increased endothelium-dependent vasodilation in the overweight and obese patients to levels similar to those of lean controls. A number of mechanisms may underline the improved endothelium-dependent vasodilator responsiveness following blockade of $\mathrm{ET}_{\mathrm{A}}$ receptors in obese vessels, including removal of $\mathrm{ET}_{\mathrm{A}}$-mediated inhibition of NO synthase or decrease in ET-1-induced oxidative stress (Callera et al. 2003, Iglarz and Clozel 2007). An alternative explanation relates to the possibility that blockade of $\mathrm{ET}_{\mathrm{A}}$ receptors might unleash ET-1 stimulation of endothelial $\mathrm{ET}_{\mathrm{B}}$ receptors, with an ensuing increase in NO production (Verhaar et al. 1998); however, this hypothesis seems less likely, given that nonselective $\mathrm{ET}_{\mathrm{A}}+\mathrm{ET}_{\mathrm{B}}$ blockade by combined infusion of BQ-123 and BQ-788 has shown to enhance the responsiveness to acetylcholine in overweight hypertensive patients (Cardillo et al. 2002). In line with previous results, we have more recently observed higher ET-1-dependent vasoconstriction in patients with metabolic abnormalities than in those with metabolically healthy obesity (Schinzari et al. 2015), hence confirming that the presence of metabolic changes results in incremental endothelial dysfunction. Taken together, the bulk of studies collected to date by our and other laboratories strongly and consistently indicates that the ET-1 system is activated in human obesity and is associated with impaired NO bioactivity, hence leading to abnormal vasodilator function. It must be noted that most of these studies included a limited number of patients and were performed by acute intravascular administration of ET-1 receptor antagonists. However, indirect support to that evidence stems from the results of a few larger, long-term studies testing orally active ET-1 receptor blockers. Thus, administration of the $\mathrm{ET}_{\mathrm{A}}$ receptor antagonist atresantan for 6 months has proven effective in improving coronary endothelial function (Reriani et al. 2010) and attenuating coronary plaque progression (Yoon et al. 2013) in patients with early atherosclerosis. Importantly, treatment with the dual $\mathrm{ET}_{\mathrm{A}}+\mathrm{ET}_{\mathrm{B}}$ blocker bosentan for 4 weeks has shown to improve endothelial function in patients with type 2 diabetes and microalbuminuria (Rafnsson et al. 2012).

\section{Vascular insulin resistance}

An important aspect of vascular dysfunction in obesity relates to the physiological actions of insulin in blood vessels and to the consequence of insulin resistance on vascular homeostasis.

\section{Physiological vascular effects of insulin}

Insulin receptors are present on endothelial cells, where they activate both the phosphatidylinositol (PI) 3-kinase/Akt pathway and the MAP kinase cascade, leading to NO and ET-1 synthesis, respectively (Muniyappa et al. 2008, Zeng et al. 2000) (Fig. 1). Evidence of the concurrent insulin-induced stimulation of both the NO pathway and the ET-1 system in humans was first collected by our group in the forearm circulation of healthy volunteers, where simultaneous blockade of $\mathrm{ET}_{\mathrm{A}}$ and $\mathrm{ET}_{\mathrm{B}}$ receptors by combined infusion of $\mathrm{BQ}-123$ and $\mathrm{BQ}-788$ was associated with a significant vasodilator response during hyperinsulinemia, but not during saline (Cardillo et al. 1999). Furthermore, during ET-1 receptor blockade, the vasoconstrictor response to NO synthesis inhibition with L-NMMA was significantly higher after insulin infusion than in the absence of hyperinsulinemia, indicating a concurrent increment in NO bioavailability. Under physiological conditions, insulin-induced release of NO may lead to expansion of the available capillary surface area in peripheral tissues, particularly in the skeletal muscle, thus augmenting the delivery of insulin itself, glucose, and other nutrients to the metabolically active tissues (Clark et al. 2003).

\section{Changes of insulin actions in obesity}

This functional coupling between the microvascular effects of insulin, muscle perfusion and glucose utilization, however, seems to be impaired in insulin resistant states like obesity and type 2 diabetes (Clark 2008), where a pathway-specific insulin resistance seems to take place at the vascular level. In fact, a pivotal biochemical defect in these patients is an impairment of 


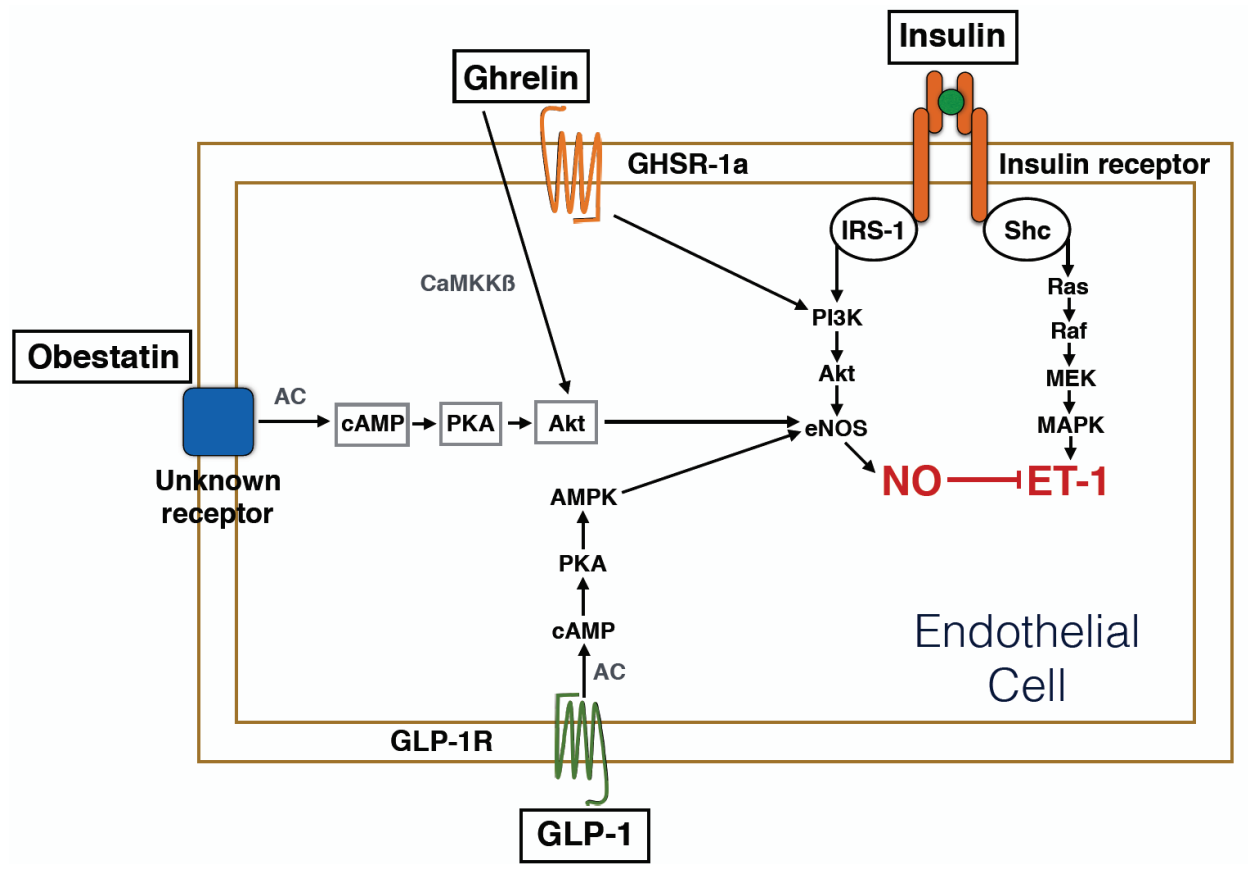

Fig. 1. Schematic representation of transduction pathways influencing the endothelial balance between nitric oxide (NO) and endothelin (ET)-1 in response to various gut hormones. Under normal physiological conditions, NO production by endothelial cells tonically inhibits ET-1 activity. By contrast, in conditions of impaired NO availability, such as obesity, unmitigated ET-1 activity may lead to enhanced vasoconstriction; under these circumstances, substances like GLP-1, ghrelin or obestatin may increase NO availability, hence resulting in decreased ET-1-mediated vasoconstrictor tone. Note that NO inhibition on ET-1 may occur at various levels, including decreased synthesis of ET-1, diminished conversion of big-ET-1 to ET-1, inhibition of the exocytosis of Weibel-Palade bodies, decrease of the constrictor effect of ET-1 via inhibition of receptor binding or downstream signaling. Activation of NO synthase by ghrelin may also occur through a GHSR-1a (ghrelin receptor-1a)-independent mechanism. IRS-1, insulin receptor substrate-1; PI3K, phosphatidylinositol 3-kinase; eNOS, endothelial NO synthase; MEK, mitogen-activated protein kinase kinase; MAPK, mitogen-activated protein kinase; AC, adenylate cyclase; PKA, phosphokinase A; AMPK, AMP-activated protein kinase; CaMKK $\beta$, $\mathrm{Ca}^{2+} / \mathrm{calmodulin}^{-}$ dependent protein kinase kinase $\beta$; GLP-1R, glucagon-like peptide-1 receptor. The pointed arrows indicate activation, the blunted arrow indicates inhibition.

the PI 3-kinase-dependent signaling cascade, while the MAP kinase pathway is spared (Cusi et al. 2000). Given the compensatory hyperinsulinemia occurring to maintain euglycemia in insulin resistant states, the potential pathophysiological implications of this abnormality become relevant. Thus, hyperinsulinemia overstimulates the normally functioning MAP kinase-dependent pathways, an effect that cannot be balanced by the abnormal PI 3-kinase cascade, hence leading to increased endothelial production of ET-1 and consequent vasoconstriction (Kim et al. 2006). This higher ET-1dependent tone may also be responsible for the defective insulin enhancement of vasodilator responses seen in the obese vasculature. We have indeed observed that, in lean subjects, insulin potentiates the responses to a variety of vasodilators acting through disparate mechanisms; by contrast, in obese patients this generalized effect of insulin to facilitate vasodilation is lost (Schinzari et al. 2010). These results have been later reproduced by Christou et al. (2012), who have reported reduced vascular smooth muscle responsiveness to exogenous NO in healthy adults with increased adiposity. In addition to augmented ET-1 dependent vasoconstriction, defective cGMP inhibition of Rho kinase in vascular smooth muscle cells (Sandu et al. 2001) or reduced endotheliumderived hyperpolarization due to $\mathrm{K}^{+}$channel dysfunction (Busija et al. 2006, Dimitropoulou et al. 2002) are other mechanisms potentially involved in this abnormality. Overall, impaired insulin-mediated vasodilation may contribute to the pathophysiology of the metabolic syndrome, because decreased muscle perfusion may blunt glucose disposal and impair glucose tolerance; similarly, reduced exposure of circulating triglyceride-containing lipoproteins to endothelial lipoprotein lipase may contribute to dyslipidemia (Lind and Lithell 1993). This suggests that microvascular dysfunction takes part in the development of insulin resistance and metabolic syndrome, which, in turn, perpetuate and amplify this vicious circle. This view is strengthened by the results of studies showing that vasoconstriction induced by infusion of exogenous ET-1 causes peripheral insulin resistance in healthy humans (Ottosson-Seeberger et al. 1997) and 
reduces glucose uptake in human skeletal muscle with concurrent impairment of both endothelium-dependent and -independent vasorelaxation (Shemyakin et al. 2011). Conversely, blockade of ET-1 receptors acutely improves insulin sensitivity in insulin resistant obese patients with coronary artery disease (Ahlborg et al. 2007); of note, combined $\mathrm{ET}_{\mathrm{A}}+\mathrm{ET}_{\mathrm{B}}$ blockade resulted more effective than selective $\mathrm{ET}_{\mathrm{A}}$ antagonism in enhancing whole-body glucose uptake during hyperinsulinemic-euglycemic clamp, thereby suggesting that $\mathrm{ET}_{\mathrm{B}}$ receptors contribute to ET-1-mediated insulin resistance in those patients.

Role of perivascular adipose tissue (PVAT) in obesity-related insulin resistance

A number of studies give substantial support to the hypothesis that changes occurring in obese PVAT, the fad pad that surrounds large, medium and small vascular beds in disparate circulatory districts, are instrumental in the development of vascular insulin resistance. Thus, under physiological conditions PVAT exerts vasodilator, anti-contractile and anti-proliferative actions, largely mediated by secretion of protective adipokines or vasodilator molecules like angiotensin-(1-7) (Aghamohammadzadeh et al. 2012, Xia and Li 2017). These molecules may signal to the vessel wall both in paracrine fashion and via outside-to-inside stream conveyed by vasa vasorum, and inhibit the responsiveness to a variety of vasoconstrictors, including ET-1 (Szasz et al. 2013). However, the favorable properties of PVAT are typically lost in the setting of obesity, when decreased production of protective adipokines and increased production of inflammatory cytokines (Chatterjee et al. 2009), such as IL-1, IL-6 and TNF- $\alpha$, impair vascular function (Lastra and Manrique 2015). Thus, by use of a variety of insulin-activated signaling pathway inhibitors, it has been shown that the fat around the nutrient arteries of obese animals selectively impairs the PI 3-kinase signaling pathway, thereby suppressing endothelial production of NO (Mazurek et al. 2003) and leading to defective postprandial increases in nutritive flow (Yudkin et al. 2005). The predominant source of these cytokines in obese PVAT are likely to be the macrophages recruited from the circulation or the activated locally resident macrophages (Weisberg et al. 2003). Among the inflammatory cytokines involved in obesity-induced vascular insulin resistance, TNF- $\alpha$ has been best characterized for its effects to interfere with IRS-1 and Akt phosphorylation and with the AMP-kinase signaling pathway (Hotamisligil and Spiegelman 1994, Plomgaard et al. 2005, Steinberg et al. 2006). In addition, TNF- $\alpha$ induces insulin resistance through activation of the MAP kinase pathway (Li et al. 2007) and may directly impair endothelial function (Bhagat and Vallance 1997). It is conceivable that excess TNF- $\alpha$ generated within or around blood vessels, rather than that originating from remote sources, is involved in the obesity-related disruption of vascular insulin signaling, given the low circulating concentrations of this cytokine. Clinical evidence supporting a role of TNF- $\alpha$ in vascular insulin resistance has been gathered in our laboratory, by demonstration that neutralizing TNF- $\alpha$ with the monoclonal antibody infliximab ameliorates the defective insulin potentiation of vasodilator responses in patients with the metabolic syndrome (Tesauro et al. 2008). Another mechanism contributing to downregulation of vascular insulin signaling relates to increased concentrations of free fatty acids (FFA) in obese adipose tissue. Interestingly, the actions of FFA in this regard are very similar to those of TNF- $\alpha$, consisting in the activation of those inflammatory pathways leading to inhibition of insulin signaling (Shoelson et al. 2006). Thus, elevated concentrations of FFA, as seen in obese fat, lead to serine/threonine phosphorylation of insulin receptor substrates (IRS-1 and IRS-2), with consequent decrease of PI 3-kinase activation and NO production (Shulman 2000). This effect seems to occur through involvement of protein kinase $\mathrm{C} \theta$ ( $\mathrm{PKC} \theta$ ) (Griffin et al. 1999), but also direct action of FFA on the NO synthase enzyme may contribute to impaired endotheliumdependent vasodilation (Steinberg and Baron 2002).

\section{Vascular effects of gut hormones: a possible target for cardiometabolic prevention}

The need for effective treatments to prevent the untoward metabolic and cardiovascular complications of obesity is suggested by the disappointing results of a number of clinical studies showing that, despite optimal glycemic control, conventional treatment of type 2 diabetes is not associated with substantial reduction of the cardiovascular outcomes. Recently, however, a few studies have shown positive cardiovascular outcomes in patients with type 2 diabetes undergoing to novel therapies for glycemic control in addition to their standard-care regimen (Marso et al. 2016a, Marso et al. 2016b, Zinman et al. 2015). 


\section{Glucagon-like peptide (GLP)-1}

Two of these recent trials have tested therapies based on degradation-resistant glucagon-like peptide (GLP)-1 analogues. Thus, in the LEADER trial, those patients with type 2 diabetes and high risk of cardiovascular disease randomized to receive the GLP-1 receptor agonist liraglutide had fewer deaths from cardiovascular causes, nonfatal myocardial infarction or nonfatal stroke compared to the placebo group (Marso et al. 2016b). Similarly, in the SUSTAIN-6 trial type 2 diabetic patients, in large part with established cardiovascular or chronic renal disease, who received the extended half-life GLP-1 analogue semaglutide had lower incidence of the primary end-point, defined as first occurrence of cardiovascular death, nonfatal myocardial infarction or nonfatal stroke, compared to those who received placebo (Marso et al. 2016a). Of note, the reduction in cardiovascular morbidity and mortality afforded by GLP-1-based therapies was independent from a tiny improvement in glucose control, thereby suggesting that the pattern of ancillary benefits of this gut peptide on the cardiovascular system was the likely driver of the observed effects.

\section{Cardiometabolic benefits of GLP-1}

GLP-1 has been originally known for its role as incretin stimulating glucose-dependent insulin secretion following meal ingestion. However, subsequent evidence has shown extended metabolic actions of GLP-1, including stimulation of pancreatic $\beta$ cell proliferation and survival, suppression of glucagon secretion from $\alpha$ cells, inhibition of gastrointestinal motility with delayed absorption of nutrients and enhanced satiety, reduction of appetite and body weight (Drucker 2016). In addition to these effects on glucose metabolism and energy homeostasis, GLP-1 also acts on the immune system to suppress inflammation and oxidative stress, improves left ventricular function, reduces lipid synthesis and secretion, inhibits platelet aggregation and thrombus formation, increases diuresis and natriuresis; the latter effect seems mediated by activation of GLP-1 receptors in atrial cardiomyocytes, leading to secretion of atrial natriuretic peptide (ANP) and vascular smooth muscle relaxation (Kim et al. 2013). Accordingly, favorable actions of GLP-1 have also been observed on blood pressure, regional blood flow and endothelial function, even though the role of GLP-1 to enhance endotheliumdependent vasodilation is disputed (Kim et al. 2013). A study performed by us has tested the effects of intra- arterial infusion of exogenous GLP-1 on vasodilator responses to acetylcholine and sodium nitroprusside in patients with the metabolic syndrome. We have observed that, during the concurrent infusion of saline, administration of GLP-1 does not modify vasodilator reactivity in these patients; during hyperinsulinemia, by contrast, infusion of GLP-1 improves the responses to both drugs, thereby suggesting that the peptide may restore the insulin signaling within the vessel wall. This effect of GLP-1 is likely related to reduced oxidative stress, because no further improvement in vasodilator reactivity is observed following GLP-1 during infusion of the antioxidant vitamin C (Tesauro et al. 2013). Potential mechanisms by which GLP-1 may quench oxidative stress within the vasculature include reduction in lipid peroxidation (Ozyazgan et al. 2005) and decreased expression of receptor for advanced glycation end products (RAGE), with subsequent decrease in the formation of reactive oxygen species (ROS) (Aroor et al. 2014, Ishibashi et al. 2013, Matsui et al. 2011).

\section{Interactions between GLP-1 and the ET-1 system}

Evidence that GLP-1 might also act as an inhibitor of the ET-1 system stems predominantly from experimental studies. Thus, Dai et al. (2013) have demonstrated that the GLP-1 receptor agonist liraglutide inhibits ET-1 in endothelial cells exposed to high glucose concentrations by repressing the phosphorylation/ activation of nuclear factor- $\mathrm{\kappa}$; moreover, generation of IL-1, a powerful pro-inflammatory molecule released by endothelial cells, was blunted by liraglutide (Dai et al. 2013). More recently, liraglutide has also shown to prevent and reverse monocrotaline-induced pulmonary arterial hypertension by suppressing ET-1 and enhancing eNOS/SGP/PKG pathways (Lee et al. 2016). In another study, prevention of GLP-1 breakdown by the DDP-4 inhibitor sitagliptin has proven able to reduce ET-1 expression in the aortic endothelium of rats with streptozotocin-induced diabetes by suppressing nuclear factor- $\mathrm{\kappa B}$ through up-regulation of AMP-activated protein kinase (Tang et al. 2016). In keeping with preclinical evidence, a study conducted in humans has also shown the effectiveness of GLP-1 analogues to inhibit ET-1. Thus, Gurkan et al. (2014) enrolled 34 insulin and incretin-naïve patients with type 2 diabetes on metformin and randomized them to exenatide or insulin glargine treatment arms. After 26 weeks, the levels of hs-CRP and endothelin-1 decreased (27.5\% and $18.75 \%$, respectively) in the exenatide arm; by contrast, 
the levels of fibrinogen, monocyte chemoattractant protein-1, leptin and ET-1 increased in the insulin glargine $\operatorname{arm}(13.4 \%, 30.2 \%, 47.5 \%$, and $80 \%$, respectively) (Gurkan et al. 2014). Taken together, both experimental and clinical data suggest that inhibition of the ET-1 system participates in the cardiovascular benefits of GLP-1-based therapies, indicating the need for further studies to directly test the efficacy of GLP-1 in reducing the up-regulated ET-1 system in the vasculature of obese patients.

\section{Ghrelin gene products}

GLP-1 is by far the most extensively studied gut hormone with translational impact, but other products of the gastrointestinal system, a large endocrine organ, are actively investigated for their role in obesity and related cardiometabolic disease. These efforts have the objective of identifying novel or combination therapies that could maximize the benefits, while concurrently reducing the side effects, of currently available individual drugs (Chakradhar 2016).

\section{Ghrelin}

One substance with properties to enhance the GLP-1 secretory response to ingested nutrients is the gastric-derived hormone ghrelin, a key regulator of food intake and whole-body energy metabolism (Muller et al. 2015). Recent studies have indeed demonstrated that pretreatment with ghrelin increases GLP-1 secretion and improves glucose metabolism in experimental models (Gagnon et al. 2015). Because GLP-1 is secreted following food ingestion, while ghrelin circulating levels increase immediately before meal times, it is likely that the pre-meal ghrelin surge acts to prime the intestinal cells to release GLP-1 in response to the upcoming meal. Conversely, ghrelin receptor antagonism results in lower circulating levels of GLP-1, with similar impairment in insulin response and glucose clearance following glucose load, hence strengthening the role of ghrelin as regulator of GLP-1 secretion and glucose handling. In addition to its effects on energy metabolism and glucose homeostasis, ghrelin has also shown favorable actions on the cardiovascular system (Fig. 1). Thus, experimental studies have demonstrated that ghrelin and its receptor are widely distributed in the heart and the vasculature, where up-regulation of the ghrelin system results in positive inotropic response, drop in blood pressure and vasodilation (Isgaard and Granata 2011). In the human circulation, we have observed that administration of exogenous ghrelin improves endothelium-dependent vasodilation in patients with obesity-related metabolic syndrome by increasing the bioavailability of NO (Tesauro et al. 2005). This observation has been subsequently replicated by Virdis et al. (2015), who have reported that ghrelin administration restores NO-mediated vasodilation in patients with essential hypertension by decreasing oxidative stress. Of note, in another investigation performed in our laboratory to assess the effects of ghrelin on the intravascular balance between the ET-1 system and the nitric oxide pathway (Tesauro et al. 2009), we found that exogenous ghrelin blunts the vasodilator effect of BQ-123 in obese patients but not in lean controls, hence implying an effect of this gastric peptide to reduce ET-1-dependent vasoconstrictor tone in obese arteries; in the same patients, ghrelin enhanced the vasoconstrictor response to L-NMMA, to indicate a concurrent increase in nitric oxide bioavailability (Fig. 2). In the same study, to directly test whether enhanced NO activity was the mechanism underlying suppression of ET-1 production elicited by ghrelin, the effects of exogenous ghrelin on $\mathrm{ET}_{\mathrm{A}}$-dependent vascular tone were also tested during constant infusion of a $\mathrm{NO}$ donor (sodium nitroprusside). Under those circumstances, administration of ghrelin did not affect $\mathrm{ET}_{\mathrm{A}}$-dependent vasoconstriction, hence suggesting that increased $\mathrm{NO}$ bioavailability is indeed involved in the inhibitory effect of ghrelin on $\mathrm{ET}_{\mathrm{A}}$-mediated vascular tone. Direct activation of NO synthase or decreased NO breakdown through down-regulation of inflammatory cytokines and reduction of oxidative stress are the possible ways by which ghrelin may enhance NO bioavailability (Kawczynska-Drozdz et al. 2006, Virdis et al. 2015, Xu et al. 2008). The perspectives offered by these favorable vascular actions are tempered by the consideration that ghrelin is also a key determinant of meal initiation and feeding behavior in humans; as such, it has an obesogenic potential that makes it an unlikely candidate for treatment of obesity-related complications. However, uncertainties still exist as to whether the acute orexigenic effects of ghrelin are coupled with long-term pro-obesity action.

\section{Obestatin}

Another product of the ghrelin gene, obestatin, seems provided of much more promising perspectives in this regard. Obestatin is a ghrelin-associated 23-amino acid peptide, cleaved by alternative splicing from a common precursor, prepro-ghrelin. It was originally proposed that obestatin reduces food intake and gastric 
emptying through activation of the G-protein-coupled receptor GPR39 (Zhang et al. 2005). However, these effects on feeding behavior and gastrointestinal motion have been subsequently disputed (Trovato et al. 2014) and the precise identity of its receptor(s) still remains debated. Accumulating evidence clearly demonstrates positive effects of obestatin to increase pancreatic $\beta$ cell proliferation and survival, to improve glucose uptake and insulin sensitivity and to inhibit lipolysis in human adipocytes (Cowan et al. 2016, Granata et al. 2012). In addition to these metabolic properties, obestatin has also shown vascular benefits in experimental models, where it improves endothelial function by increasing NO production via an adenylate cyclase-linked $\mathrm{G}$ proteincoupled receptor (Agnew et al. 2012) (Fig. 1). We have recently compared the effects of exogenous obestatin on forearm flow in lean subjects and obese patients, assessing also its influence on the obesity-related increase of ET-1-dependent vasoconstriction (Schinzari et al. 2017). We have observed that infusion of escalating doses of obestatin results in a progressive vasodilation in both lean and obese subjects; this vasodilation is predominantly mediated by enhanced NO activity, because L-NMMA markedly blunts the flow response to obestatin in both groups. In obese patients, antagonism of $\mathrm{ET}_{\mathrm{A}}$ receptors by $\mathrm{BQ}-123$ increases forearm flow during saline, but does not result in any additional vasodilation during obestatin (Fig. 3). Taken together, these findings provide support to the notion that the obestatin signaling might be another effective target for prevention in obesity.

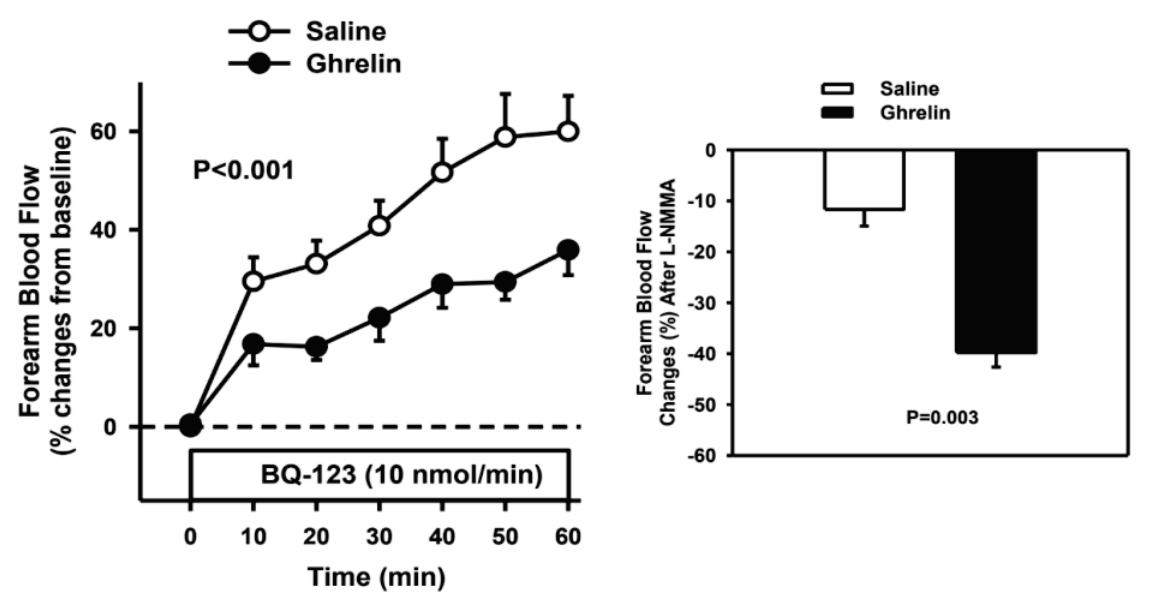

Fig. 2. Effects of exogenous ghrelin on vascular responses to $\mathrm{ET}_{\mathrm{A}}$ receptor blockade with BQ-123 (left panel) and nitric oxide synthase inhibition by L-NMMA (right panel) in obese patients. Modified from Tesauro et al. (2009).

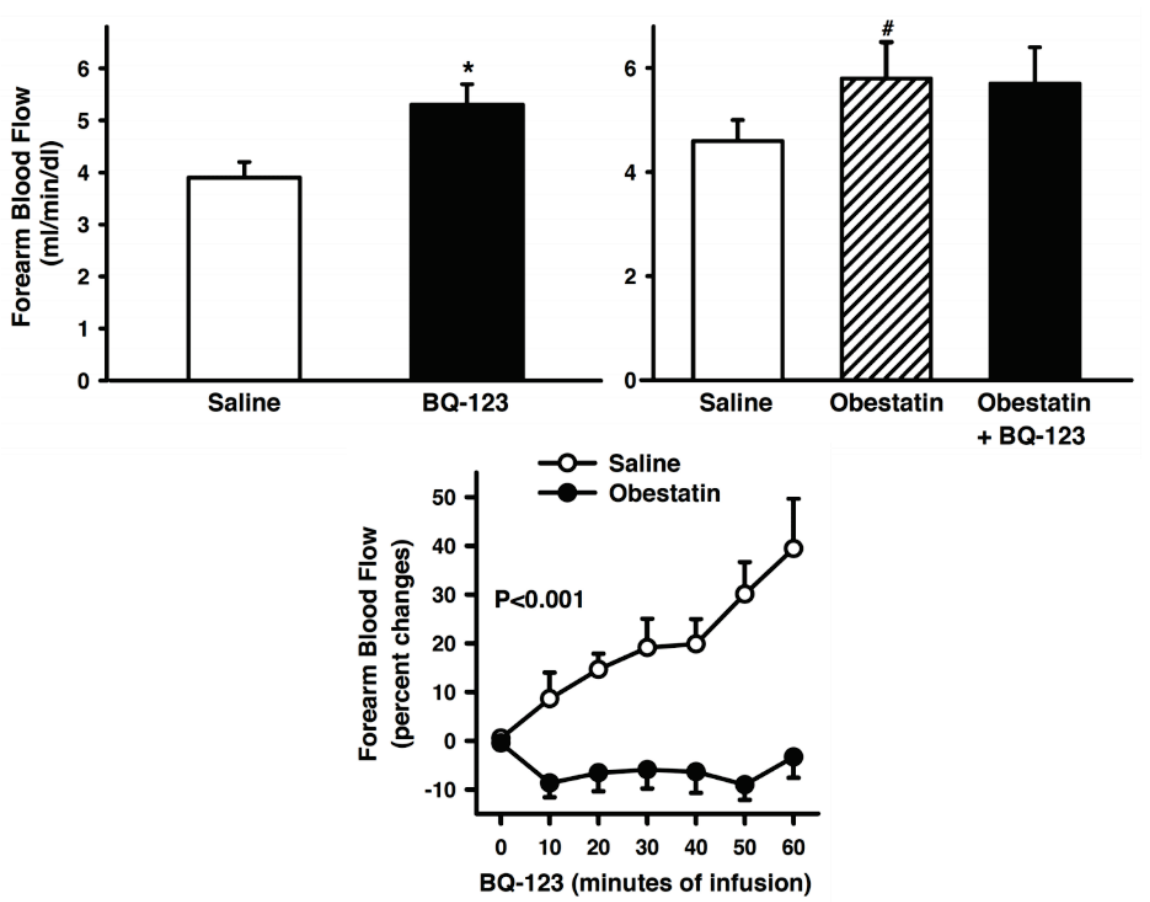

Fig. 3. Forearm blood values at baseline and during blockade of $\mathrm{ET}_{\mathrm{A}}$ receptors with BQ-123 (bottom panel), in the absence (top, left panel) or the presence (top, right panel) of exogenous obestatin in obese patients. ${ }^{* P}=0.002$ and $\# \mathrm{P}=0.009$ compared to saline. Percent changes in forearm flow from baseline in response to $\mathrm{ET}_{\mathrm{A}}$ receptor blockade with $\mathrm{BQ}-123$ in the absence or the presence of exogenous obestatin in the same patients. Modified from Schinzari et al. (2017). 


\section{Conclusions and perspectives}

Over the last few years, a bulk of evidence has accumulated to demonstrate that activation of the ET-1 system within the vessel wall is a key hemodynamic abnormality in human obesity. Among the mechanisms contributing to enhanced ET-1 activity, obesity-driven changes in PVAT make it a prominent source of mediators that lead to enhanced ET-1-mediated vasoconstriction, with concurrent reduction of nitric oxide-induced vasodilation. Changes in insulin signaling within the vessel wall then become instrumental in tipping the balance between opposing mediators toward the vasoconstrictor and pro-atherogenic forces.

With the rise of obesity in the population, there is clearly a need for therapies that could effectively prevent its metabolic and cardiovascular sequelae. Therefore, it has become of paramount importance the challenge of deploying novel effective and safe therapies. Knowledge of the homeostatic mechanisms makes it likely that multiple forces, involving a number of different signals, operate in concert to determine those perturbations in blood vessels that are associated with obesity. In this context, gut hormones might exert an important role to protect blood vessels and improve insulin sensitivity. Even though some results from recent large-scale clinical trials indicate that novel treatments of type 2 diabetes with single agents provided of cardiovascular potential may translate into clinically significant benefits, ongoing efforts are aimed at obtaining novel or combination therapies, given that targeting a single pathway is probably not sufficient (Davenport and Wright 2014). Therefore, the real hope is that better understanding of the properties of gut-derived substances might provide new possibilities for more effective dual-action treatments to tackle both the metabolic and cardiovascular abnormalities associated with obesity.

\section{Conflict of Interest}

There is no conflict of interest.

\section{Acknowledgements}

This work was supported by grants from the Fondazione Roma (NCDS-2013-00000308) and the Ministero della Salute (RF-2010-2313809) to C. Cardillo, whose research is also supported by the annual Fondi d'Ateneo grants from the Università Cattolica del Sacro Cuore.

\section{References}

AGHAMOHAMMADZADEH R, WITHERS S, LYNCH F, GREENSTEIN A, MALIK R, HEAGERTY A: Perivascular adipose tissue from human systemic and coronary vessels: the emergence of a new pharmacotherapeutic target. Br J Pharmacol 165: 670-682, 2012.

AGNEW AJ, ROBINSON E, MCVICAR CM, HARVEY AP, ALI IH, LINDSAY JE, MCDONALD DM, GREEN BD, GRIEVE DJ: The gastrointestinal peptide obestatin induces vascular relaxation via specific activation of endothelium-dependent NO signalling. Br J Pharmacol 166: 327-338, 2012.

AHIMA RS, LAZAR MA: The health risk of obesity-better metrics imperative. Science 341: 856-858, 2013.

AHLBORG G, SHEMYAKIN A, BOHM F, GONON A, PERNOW J: Dual endothelin receptor blockade acutely improves insulin sensitivity in obese patients with insulin resistance and coronary artery disease. Diabetes Care 30: 591-596, 2007.

AROOR AR, SOWERS JR, JIA G, DEMARCO VG: Pleiotropic effects of the dipeptidylpeptidase-4 inhibitors on the cardiovascular system. Am J Physiol Heart Circ Physiol 307: H477-H492, 2014.

BHAGAT K, VALLANCE P: Inflammatory cytokines impair endothelium-dependent dilatation in human veins in vivo. Circulation 96: 3042-3047, 1997.

BOULANGER C, LUSCHER TF: Release of endothelin from the porcine aorta. Inhibition by endothelium-derived nitric oxide. J Clin Invest 85: 587-590, 1990.

BUSIJA DW, MILLER AW, KATAKAM P, ERDOS B: Adverse effects of reactive oxygen species on vascular reactivity in insulin resistance. Antioxid Redox Signal 8: 1131-1140, 2006.

CALLERA GE, TOUYZ RM, TEIXEIRA SA, MUSCARA MN, CARVALHO MH, FORTES ZB, NIGRO D, SCHIFFRIN EL, TOSTES RC: ETA receptor blockade decreases vascular superoxide generation in DOCA-salt hypertension. Hypertension 42: 811-817, 2003. 
CARDILLO C, NAMBI SS, KILCOYNE CM, CHOUCAIR WK, KATZ A, QUON MJ, PANZA JA: Insulin stimulates both endothelin and nitric oxide activity in the human forearm. Circulation 100: 820-825, 1999.

CARDILLO C, CAMPIA U, BRYANT MB, PANZA JA: Increased activity of endogenous endothelin in patients with type II diabetes mellitus. Circulation 106: 1783-1787, 2002.

CARDILLO C, CAMPIA U, IANTORNO M, PANZA JA: Enhanced vascular activity of endogenous endothelin-1 in obese hypertensive patients. Hypertension 43: 36-40, 2004.

CHAKRADHAR S: All in one: researchers create combination drugs for diabetes and obesity. Nat Med 22: 694-696, 2016.

CHATTERJEE TK, STOLL LL, DENNING GM, HARRELSON A, BLOMKALNS AL, IDELMAN G, ROTHENBERG FG, NELTNER B, ROMIG-MARTIN SA, DICKSON EW, RUDICH S, WEINTRAUB NL: Proinflammatory phenotype of perivascular adipocytes: influence of high-fat feeding. Circ Res 104: 541-549, 2009.

CHRISTOU DD, PIERCE GL, WALKER AE, HWANG MH, YOO JK, LUTTRELL M, MEADE TH, ENGLISH M, SEALS DR: Vascular smooth muscle responsiveness to nitric oxide is reduced in healthy adults with increased adiposity. Am J Physiol Heart Circ Physiol 303: H743-H750, 2012.

CLARK MG: Impaired microvascular perfusion: a consequence of vascular dysfunction and a potential cause of insulin resistance in muscle. Am J Physiol Endocrinol Metab 295: E732-E750, 2008.

CLARK MG, WALLIS MG, BARRETT EJ, VINCENT MA, RICHARDS SM, CLERK LH, RATTIGAN S: Blood flow and muscle metabolism: a focus on insulin action. Am J Physiol Endocrinol Metab 284: E241-E258, 2003.

COWAN E, BURCH KJ, GREEN BD, GRIEVE DJ: Obestatin as a key regulator of metabolism and cardiovascular function with emerging therapeutic potential for diabetes. Br J Pharmacol 173: 2165-2181, 2016.

CUSI K, MAEZONO K, OSMAN A, PENDERGRASS M, PATTI ME, PRATIPANAWATR T, DEFRONZO RA, KAHN CR, MANDARINO LJ: Insulin resistance differentially affects the PI 3-kinase- and MAP kinasemediated signaling in human muscle. J Clin Invest 105: 311-320, 2000.

DAI Y, MEHTA JL, CHEN M: Glucagon-like peptide-1 receptor agonist liraglutide inhibits endothelin-1 in endothelial cell by repressing nuclear factor-kappa B activation. Cardiovasc Drugs Ther 27: 371-380, 2013.

DAVENPORT RJ, WRIGHT S: Treating obesity: is it all in the gut? Drug Discov Today 19: 845-858, 2014.

DIMITROPOULOU C, HAN G, MILLER AW, MOLERO M, FUCHS LC, WHITE RE, CARRIER GO: Potassium $(\mathrm{BK}(\mathrm{Ca}))$ currents are reduced in microvascular smooth muscle cells from insulin-resistant rats. Am J Physiol Heart Circ Physiol 282: H908-H917, 2002.

DRUCKER DJ: The cardiovascular biology of glucagon-like peptide-1. Cell Metab 24: 15-30, 2016.

GAGNON J, BAGGIO LL, DRUCKER DJ, BRUBAKER PL: Ghrelin is a novel regulator of GLP-1 secretion. Diabetes 64: 1513-1521, 2015.

GRANATA R, GALLO D, LUQUE RM, BARAGLI A, SCARLATTI F, GRANDE C, GESMUNDO I, CORDOBACHACON J, BERGANDI L, SETTANNI F, TOGLIATTO G, VOLANTE M, GARETTO S, ANNUNZIATA M, CHANCLON B, GARGANTINI E, ROCCHIETTO S, MATERA L, DATTA G, MORINO M, BRIZZI MF, ONG H, CAMUSSI G, CASTANO JP, PAPOTTI M, GHIGO E: Obestatin regulates adipocyte function and protects against diet-induced insulin resistance and inflammation. FASEB J 26: 3393-3411, 2012.

GRIFFIN ME, MARCUCCI MJ, CLINE GW, BELL K, BARUCCI N, LEE D, GOODYEAR LJ, KRAEGEN EW, WHITE MF, SHULMAN GI: Free fatty acid-induced insulin resistance is associated with activation of protein kinase C theta and alterations in the insulin signaling cascade. Diabetes 48: 1270-1274, 1999.

GURKAN E, TARKUN I, SAHIN T, CETINARSLAN B, CANTURK Z: Evaluation of exenatide versus insulin glargine for the impact on endothelial functions and cardiovascular risk markers. Diabetes Res Clin Pract 106: 567-575, 2014.

HOTAMISLIGIL GS, SPIEGELMAN BM: Tumor necrosis factor alpha: a key component of the obesity-diabetes link. Diabetes 43: 1271-1278, 1994.

IGLARZ M, CLOZEL M: Mechanisms of ET-1-induced endothelial dysfunction. J Cardiovasc Pharmacol 50: 621-628, 2007. 
ISGAARD J, GRANATA R: Ghrelin in cardiovascular disease and atherogenesis. Mol Cell Endocrinol 340: 59-64, 2011.

ISHIBASHI Y, MATSUI T, MAEDA S, HIGASHIMOTO Y, YAMAGISHI S: Advanced glycation end products evoke endothelial cell damage by stimulating soluble dipeptidyl peptidase-4 production and its interaction with mannose 6-phosphate/insulin-like growth factor II receptor. Cardiovasc Diabetol 12: 125, 2013.

KAWCZYNSKA-DROZDZ A, OLSZANECKI R, JAWIEN J, BRZOZOWSKI T, PAWLIK WW, KORBUT R, GUZIK TJ: Ghrelin inhibits vascular superoxide production in spontaneously hypertensive rats. $\mathrm{Am} J$ Hypertens 19: 764-767, 2006.

KIM JA, MONTAGNANI M, KOH KK, QUON MJ: Reciprocal relationships between insulin resistance and endothelial dysfunction: molecular and pathophysiological mechanisms. Circulation 113: 1888-1904, 2006.

KIM M, PLATT MJ, SHIBASAKI T, QUAGGIN SE, BACKX PH, SEINO S, SIMPSON JA, DRUCKER DJ: GLP-1 receptor activation and Epac2 link atrial natriuretic peptide secretion to control of blood pressure. Nat Med 19: 567-575, 2013.

LASTRA G, MANRIQUE C: Perivascular adipose tissue, inflammation and insulin resistance: link to vascular dysfunction and cardiovascular disease. Horm Mol Biol Clin Investig 22: 19-26, 2015.

LEE MJ, WU Y, FRIED SK: Adipose tissue heterogeneity: implication of depot differences in adipose tissue for obesity complications. Mol Aspects Med 34: 1-11, 2013.

LEE MY, TSAI KB, HSU JH, SHIN SJ, WU JR, YEH JL: Liraglutide prevents and reverses monocrotaline-induced pulmonary arterial hypertension by suppressing ET-1 and enhancing eNOS/sGC/PKG pathways. Sci Rep 6: 31788, 2016.

LI G, BARRETT EJ, BARRETT MO, CAO W, LIU Z: Tumor necrosis factor-alpha induces insulin resistance in endothelial cells via a p38 mitogen-activated protein kinase-dependent pathway. Endocrinology 148: 3356-3363, 2007.

LIND L, LITHELL H: Decreased peripheral blood flow in the pathogenesis of the metabolic syndrome comprising hypertension, hyperlipidemia, and hyperinsulinemia. Am Heart J 125: 1494-1497, 1993.

MARSO SP, BAIN SC, CONSOLI A, ELIASCHEWITZ FG, JODAR E, LEITER LA, LINGVAY I, ROSENSTOCK J, SEUFERT J, WARREN ML, WOO V, HANSEN O, HOLST AG, PETTERSSON J, VILSBOLL T: Semaglutide and cardiovascular outcomes in patients with type 2 diabetes. $N$ Engl J Med 375: 1834-1844, 2016a.

MARSO SP, DANIELS GH, BROWN-FRANDSEN K, KRISTENSEN P, MANN JF, NAUCK MA, NISSEN SE, POCOCK S, POULTER NR, RAVN LS, STEINBERG WM, STOCKNER M, ZINMAN B, BERGENSTAL RM, BUSE JB: Liraglutide and cardiovascular outcomes in type 2 diabetes. $N$ Engl $J$ Med 375: 311-322, 2016b.

MATHER KJ, LTEIF A, STEINBERG HO, BARON AD: Interactions between endothelin and nitric oxide in the regulation of vascular tone in obesity and diabetes. Diabetes 53: 2060-2066, 2004.

MATSUI T, NISHINO Y, TAKEUCHI M, YAMAGISHI S: Vildagliptin blocks vascular injury in thoracic aorta of diabetic rats by suppressing advanced glycation end product-receptor axis. Pharmacol Res 63: 383-388, 2011.

MAZUREK T, ZHANG L, ZALEWSKI A, MANNION JD, DIEHL JT, ARAFAT H, SAROV-BLAT L, O'BRIEN S, KEIPER EA, JOHNSON AG, MARTIN J, GOLDSTEIN BJ, SHI Y: Human epicardial adipose tissue is a source of inflammatory mediators. Circulation 108: 2460-2466, 2003.

MULLER TD, NOGUEIRAS R, ANDERMANN ML, ANDREWS ZB, ANKER SD, ARGENTE J, BATTERHAM RL, BENOIT SC, BOWERS CY, BROGLIO F, CASANUEVA FF, D'ALESSIO D, DEPOORTERE I, GELIEBTER A, GHIGO E, COLE PA, COWLEY M, CUMMINGS DE, DAGHER A, DIANO S, DICKSON SL, DIEGUEZ C, GRANATA R, GRILL HJ, GROVE K, HABEGGER KM, HEPPNER K, HEIMAN ML, HOLSEN L, HOLST B, INUI A, JANSSON JO, KIRCHNER H, KORBONITS M, LAFERRERE B, LEROUX CW, LOPEZ M, MORIN S, NAKAZATO M, NASS R, PEREZ-TILVE D, PFLUGER PT, SCHWARTZ TW, SEELEY RJ, SLEEMAN M, SUN Y, SUSSEL L, TONG J, THORNER MO, VAN DER LELY AJ, VAN DER PLOEG LH, ZIGMAN JM, KOJIMA M, KANGAWA K, SMITH RG, HORVATH T, TSCHOP MH: Ghrelin. Mol Metab 4: 437-460, 2015. 
MUNIYAPPA R, IANTORNO M, QUON MJ: An integrated view of insulin resistance and endothelial dysfunction. Endocrinol Metab Clin North Am 37: 685-711, 2008.

OTTOSSON-SEEBERGER A, LUNDBERG JM, ALVESTRAND A, AHLBORG G: Exogenous endothelin-1 causes peripheral insulin resistance in healthy humans. Acta Physiol Scand 161: 211-220, 1997.

OZYAZGAN S, KUTLUATA N, AFSAR S, OZDAS SB, AKKAN AG: Effect of glucagon-like peptide-1(7-36) and exendin-4 on the vascular reactivity in streptozotocin/nicotinamide-induced diabetic rats. Pharmacology 74: 119-126, 2005.

PLOMGAARD P, BOUZAKRI K, KROGH-MADSEN R, MITTENDORFER B, ZIERATH JR, PEDERSEN BK: Tumor necrosis factor-alpha induces skeletal muscle insulin resistance in healthy human subjects via inhibition of Akt substrate 160 phosphorylation. Diabetes 54: 2939-2945, 2005.

RAFNSSON A, BOHM F, SETTERGREN M, GONON A, BRISMAR K, PERNOW J: The endothelin receptor antagonist bosentan improves peripheral endothelial function in patients with type 2 diabetes mellitus and microalbuminuria: a randomised trial. Diabetologia 55: 600-607, 2012.

RERIANI M, RAICHLIN E, PRASAD A, MATHEW V, PUMPER GM, NELSON RE, LENNON R, RIHAL C, LERMAN LO, LERMAN A: Long-term administration of endothelin receptor antagonist improves coronary endothelial function in patients with early atherosclerosis. Circulation 122: 958-966, 2010.

SANDU OA, ITO M, BEGUM N: Insulin utilizes NO/cGMP pathway to activate myosin phosphatase via Rho inhibition in vascular smooth muscle. J Appl Physiol (1985) 91: 1475-1482, 2001.

SCHINZARI F, TESAURO M, ROVELLA V, GALLI A, MORES N, PORZIO O, LAURO D, CARDILLO C: Generalized impairment of vasodilator reactivity during hyperinsulinemia in patients with obesity-related metabolic syndrome. Am J Physiol Endocrinol Metab 299: E947-E952, 2010.

SCHINZARI F, IANTORNO M, CAMPIA U, MORES N, ROVELLA V, TESAURO M, DI DANIELE N, CARDILLO C: Vasodilator responses and endothelin-dependent vasoconstriction in metabolically healthy obesity and the metabolic syndrome. Am J Physiol Endocrinol Metab 309: E787-E792, 2015.

SCHINZARI F, VENEZIANI A, MORES N, BARINI A, DI DANIELE N, CARDILLO C, TESAURO M: Vascular effects of obestatin in lean and obese subjects. Diabetes 66: 1214-1221, 2017.

SHEMYAKIN A, SALEHZADEH F, ESTEVES DUQUE-GUIMARAES D, BOHM F, RULLMAN E, GUSTAFSSON T, PERNOW J, KROOK A: Endothelin-1 reduces glucose uptake in human skeletal muscle in vivo and in vitro. Diabetes 60: 2061-2067, 2011.

SHOELSON SE, LEE J, GOLDFINE AB: Inflammation and insulin resistance. J Clin Invest 116: 1793-1801, 2006.

SHULMAN GI: Cellular mechanisms of insulin resistance. J Clin Invest 106: 171-176, 2000.

STEINBERG GR, MICHELL BJ, VAN DENDEREN BJ, WATT MJ, CAREY AL, FAM BC, ANDRIKOPOULOS S, PROIETTO J, GORGUN CZ, CARLING D, HOTAMISLIGIL GS, FEBBRAIO MA, KAY TW, KEMP BE: Tumor necrosis factor alpha-induced skeletal muscle insulin resistance involves suppression of AMP-kinase signaling. Cell Metab 4: 465-474, 2006.

STEINBERG HO, BARON AD: Vascular function, insulin resistance and fatty acids. Diabetologia 45: 623-634, 2002.

STEINBERG HO, CHAKER H, LEAMING R, JOHNSON A, BRECHTEL G, BARON AD: Obesity/insulin resistance is associated with endothelial dysfunction. Implications for the syndrome of insulin resistance. J Clin Invest 97: 2601-2610, 1996.

SZASZ T, BOMFIM GF, WEBB RC: The influence of perivascular adipose tissue on vascular homeostasis. Vasc Health Risk Manag 9: 105-116, 2013.

TANG ST, SU H, ZHANG Q, TANG HQ, WANG CJ, ZHOU Q, WEI W, ZHU HQ, WANG Y: Sitagliptin inhibits endothelin-1 expression in the aortic endothelium of rats with streptozotocin-induced diabetes by suppressing the nuclear factor-kappaB/IkappaBalpha system through the activation of AMP-activated protein kinase. Int $J$ Mol Med 37: 1558-1566, 2016.

TESAURO M, SCHINZARI F, IANTORNO M, RIZZA S, MELINA D, LAURO D, CARDILLO C: Ghrelin improves endothelial function in patients with metabolic syndrome. Circulation 112: 2986-2992, 2005.

TESAURO M, SCHINZARI F, ROVELLA V, MELINA D, MORES N, BARINI A, METTIMANO M, LAURO D, IANTORNO M, QUON MJ, CARDILLO C: Tumor necrosis factor-alpha antagonism improves vasodilation during hyperinsulinemia in metabolic syndrome. Diabetes Care 31: 1439-1441, 2008. 
TESAURO M, SCHINZARI F, ROVELLA V, DI DANIELE N, LAURO D, MORES N, VENEZIANI A, CARDILLO $\mathrm{C}$ : Ghrelin restores the endothelin 1/nitric oxide balance in patients with obesity-related metabolic syndrome. Hypertension 54: 995-1000, 2009.

TESAURO M, SCHINZARI F, ADAMO A, ROVELLA V, MARTINI F, MORES N, BARINI A, PITOCCO D, GHIRLANDA G, LAURO D, CAMPIA U, CARDILLO C: Effects of GLP-1 on forearm vasodilator function and glucose disposal during hyperinsulinemia in the metabolic syndrome. Diabetes Care 36: 683-689, 2013.

TROVATO L, GALLO D, SETTANNI F, GESMUNDO I, GHIGO E, GRANATA R: Obestatin: is it really doing something? Front Horm Res 42: 175-185, 2014.

VAN GUILDER GP, HOETZER GL, DENGEL DR, STAUFFER BL, DESOUZA CA: Impaired endotheliumdependent vasodilation in normotensive and normoglycemic obese adult humans. J Cardiovasc Pharmacol 47: 310-313, 2006.

VERHAAR MC, STRACHAN FE, NEWBY DE, CRUDEN NL, KOOMANS HA, RABELINK TJ, WEBB DJ: Endothelin-A receptor antagonist-mediated vasodilatation is attenuated by inhibition of nitric oxide synthesis and by endothelin-B receptor blockade. Circulation 97: 752-756, 1998.

VIRDIS A, DURANTI E, COLUCCI R, IPPOLITO C, TIROTTA E, LORENZINI G, BERNARDINI N, BLANDIZZI C, TADDEI S: Ghrelin restores nitric oxide availability in resistance circulation of essential hypertensive patients: role of NAD(P)H oxidase. Eur Heart J 36: 3023-3030, 2015.

WEIL BR, WESTBY CM, VAN GUILDER GP, GREINER JJ, STAUFFER BL, DESOUZA CA: Enhanced endothelin-1 system activity with overweight and obesity. Am J Physiol Heart Circ Physiol 301: H689-H695, 2011 .

WEISBERG SP, MCCANN D, DESAI M, ROSENBAUM M, LEIBEL RL, FERRANTE AW JR: Obesity is associated with macrophage accumulation in adipose tissue. J Clin Invest 112: 1796-1808, 2003.

WILDMAN RP, MUNTNER P, REYNOLDS K, MCGINN AP, RAJPATHAK S, WYLIE-ROSETT J, SOWERS MR: The obese without cardiometabolic risk factor clustering and the normal weight with cardiometabolic risk factor clustering: prevalence and correlates of 2 phenotypes among the US population (NHANES 1999-2004). Arch Intern Med 168: 1617-1624, 2008.

XIA N, LI H: The role of perivascular adipose tissue in obesity-induced vascular dysfunction. Br J Pharmacol 174: 3425-3442, 2017.

XU X, JHUN BS, HA CH, JIN ZG: Molecular mechanisms of ghrelin-mediated endothelial nitric oxide synthase activation. Endocrinology 149: 4183-4192, 2008.

YOON MH, RERIANI M, MARIO G, RIHAL C, GULATI R, LENNON R, TILFORD JM, LERMAN LO, LERMAN A: Long-term endothelin receptor antagonism attenuates coronary plaque progression in patients with early atherosclerosis. Int J Cardiol 168: 1316-1321, 2013.

YUDKIN JS, ERINGA E, STEHOUWER CD: "Vasocrine" signalling from perivascular fat: a mechanism linking insulin resistance to vascular disease. Lancet 365: 1817-1820, 2005.

ZENG G, NYSTROM FH, RAVICHANDRAN LV, CONG LN, KIRBY M, MOSTOWSKI H, QUON MJ: Roles for insulin receptor, PI3-kinase, and Akt in insulin-signaling pathways related to production of nitric oxide in human vascular endothelial cells. Circulation 101: 1539-1545, 2000.

ZHANG JV, REN PG, AVSIAN-KRETCHMER O, LUO CW, RAUCH R, KLEIN C, HSUEH AJ: Obestatin, a peptide encoded by the ghrelin gene, opposes ghrelin's effects on food intake. Science 310: 996-999, 2005.

ZINMAN B, WANNER C, LACHIN JM, FITCHETT D, BLUHMKI E, HANTEL S, MATTHEUS M, DEVINS T, JOHANSEN OE, WOERLE HJ, BROEDL UC, INZUCCHI SE: Empagliflozin, cardiovascular outcomes, and mortality in type 2 diabetes. $N$ Engl J Med 373: 2117-2128, 2015. 